\title{
Legal Protection Toward Consumers of Showroom in Purchasing Used Cars That are Incompatible with Those Presented in Advertisement
}

\author{
Desak Gede Dwi Arini ${ }^{1}$, AA Sagung Laksmi Dewi ${ }^{2}$, Ni Made Puspasutari Ujiati ${ }^{3}$
}

Faculty of Law Universitas Warmadewa Denpasar-Bali, Indonesia ${ }^{123}$

\begin{abstract}
Legal protection for consumers of used car showrooms, in this case, applies both to goods and services of the the same and different types. Protection for used car brands includes protection of all types of goods or services, thus imitation of a wellknown brand, owned by someone else, is basically based on "bad faith" with the aim of making a profit by utilizing the fame of someone else's brand and such actions do not obtain protection from the law. The design used in this study is the design of normative law study. There are two types of legal materials used as data of the study, namely primary legal material in the form of related laws and regulations and secondary legal material in the form of concepts obtained from literature and journals. The findings show that legal protection towardconsumer of showrooms in purchasing used cars is manifested in making binding credit agreements between consumers and showroom owners to clarify and guarantee legal certainty regarding the rights and obligations of each party. The settlement carried out to protect theconsumers in purchasing used cars, whose conditions are not in accordance with those in the advertisements of showrooms, is to implement preventive and repressive methods. In other words, preventive method, when making a loan agreement, rights, obligations and sanctions when a consumer breaks a promise (default) must be explained by the showroom. With repressive methods, if a breach of agreement is found (default), the showroom company must apply the sanctions agreed upon in the credit agreement to the consumer. Likewise, if default is carried out by a showroom company, the application of legal sanctions against used car manufacturers/business showrooms that have been proven to have committed violations must be realised, including by asking them to pay compensation to the consumers with the amount that is in accordance with the damage to the car purchased. In addition, the termination of production or sales - temporarily until the problems that occur are resolved - is enforced, apart from the revocation of production licenses or business licenses which shall also be executed.
\end{abstract}

Keywords: Legal protection, Consumer, Showroom, Used Car

\section{Introduction}

In accordance with the General Explanation of the Law of the Republic of Indonesia No. 8 of 1999 concerning Consumer Protection, the main factor that causes consumer exploitation often occurs is the low level of consumer awareness of their rights. This is certainly closely related to low consumer education. If seen further, consumers are only faced with the problem of lack of awareness and their lack of understanding of their rights as consumers. The rights referred to are for example that consumers do not have a balanced bargaining position with the business actors. This can be seen once in the standard agreement which is not informative and cannot be negotiable [1]. 
Protection of consumers, if viewed materially or formally, is increasingly perceived very important, given the increasingly rapid pace of development of science and technology which is a driving force for the productivity and efficiency of business actors for the goods and/or services they produce. In order to pursue and achieve these two objectives, finally, both directly and indirectly, there needs to be efforts to provide adequate protection to the interests of consumers [2].

Through the existence of the Republic of Indonesia Law Number 8 of 1999 concerning Consumer Protection, efforts to protect consumers in Indonesia are expected to be further enhanced so that the position of consumers themselves is not always in a weak position besides business actors can also further improve the quality of products offered to consumers. In addition, the accumulation of the various conditions and factors above has caused buyers of used cars through advertisements among the people today to be very vulnerable and susceptible to discrepancies between the actual conditions in the field and the conditions presented in the advertisements. So far no party has felt the most responsible so that all parties should sit together and discuss this issue in an integrated manner and take comprehensive steps. The lives of Indonesian people should not be valued inxepensively. As consumers, every buyer must have an interest in obtaining legal protection in relation to the quality and quantity of goods/services. A reality is that consumers occupy a very important position in the continuity of the economy, but it is very unfortunate because the consumers is in arestrengthless position.

Under various considerations regarding cases that have been rampant in the form of violations of the rights of consumers of used car purchasersvia advertisements of Showrooms, the government shall take actions to provide legal protection against them. Conversely, many prohibitions have been ignored by business actors, thus the government shall provide legal sanctions commensurate with the types of violations they have committed. This is in accordance with the provisions in the articles contained in the Law of the Republic of Indonesia Number 8 of 1999 concerning Consumer Protection.

Based on the background above, the authors are interested in examiningthe "Legal Protection toward Consumers of Showroom in Purchasing Used Cars that are Incompatible with the Conditions Presentedin the Advertisement".

Grounded the background elaborated above, there are several problems that arise, in relation to the title of the research proposed. The problemsare formulated as follows: What is the legal protection of used car consumers based on the Law of the Republic of Indonesia Number 8 of 1999? And, what is the effort to resolve used car sales cases that are incompatible with those presented in the ad?

\section{Methodology}

The type of research used in the present study is normative legal research, in which the study was conducted by carrying out library investigation to review the literature and by analyzing the applicable laws and regulations on business and sale and purchase of goods and/or services, such as Law of the Republic of Indonesia Number 40 of 2007 concerning Limited Liability Companies, and Law of the Republic of Indonesia Number 8 of 1999 about Consumer Protection.

The approaches to the problems used in this study arestatute approach and conceptual approach. What we mean by these two approaches is that here we looked at the applicable legal rules and the extent of the application of legal rules, especially regarding legal protection 
for consumers of showrooms in purchasing used cars whose conditions do not match what is stated in the ad. The legal materials used as the study data are primary legal materials in the form of law Number 8 of 1999 concerning Consumer Protection and Law Number 40 of 2007 concerning Limited Liability Companies; and secondary legal material in the form of results of previous studies conducted on Law or the application of the Law related to the purchase of used goods or objects, collected through the carrying out library investigation i.e. by reading literature, books, journals and related laws and regulations.

\section{Result and Discussion}

\subsection{Legal Protection for Consumers of Used Cars Based on Law No. 8 of 1999}

The relationship between business actors and consumers is a relationship that occurs continuously and continuously. The relationship occurs because both of them as a result of the desire to require the occurrence of mutual conditions with a high level between one another. Business people really need and are very dependent on consumer support as a customer. Without consumer support, it is impossible for businesses actors to maintain their business continuity and vice versa, consumer needs are also highly dependent on the production of business actors.

"The relationship between business actors and consumers that continues to occur since the production process, distribution to marketing, to the offer. The series of activities is a series of legal actions that have legal consequences, both for all parties and only for certain parties" [3].

Any act that violates the law, which causes harm to another person, requires that the person who caused the wrongdoing to issue the loss compensates for the loss [4].

From the provisions above, for consumers who are harmed by consuming a certain product, there is no need to be bound by an agreement to be able to claim compensation, but can also sue on the grounds that the producer commits an illegal, and the basis of the business actor's liability is the one based on the mistakes of the business actor.

The provisions of Article 4 of the Consumer Protection Act (referred to as "UUPK" in Indonesia), determine a number of consumer rights that receive guarantees and legal protection, namely the right to comfort, security and safety in consuming goods/services; the right to choose goods and or services in accordance with the conditions and guarantees promised; the right to correct, clear and honest information regarding the condition and guarantee of goods and/services; the right to be listened for opinions and complaints about the goods and or services used; the right to obtain advocacy, protection and efforts to properly resolve consumer protection disputes; and the right to get compensation for compensation and or replacement if the goods and or services received are not in accordance with the agreement.

In article 5 of the $U U P K$, a number of consumer obligations are established, namely reading and following information instructions and procedures for the use or use of goods and or services for security and safety; having a good intention in conducting transactions for the purchase of goods and or services, paying according to the agreed exchange rate; and follow the efforts to properly settle the law on consumer protection disputes.

In addition to rights and obligations that need to be considered by business actors, there are also liabilities that must be borne. These liabilities are part of the obligations that bind their activities in the business. These liabilitiesare also referred to as product liability. Product Liability is a legal responsibility of the person/entity that produces a product 
(producer/manufacturer) and from a person/body that is engaged in a process to produce a product (processor/assembler) or distribute (seller/distributor) the product" [4]

The implementation of the liability product concept is apparently complicated, because in a conventional accountability system, product liability is based on the existence of a default and a fault.

Based on Article 1365 of the Civil Code, consumers who suffer losses due to defective goods/services can sue the producer (business actor) directly. These demands are based on the condition that acts against law have taken place. Or in other words, consumers must first prove the mistakes made by business actors [5].

Therefore, it is necessary to apply the concept of strict liability, namely that producers must immediately be liable for losses suffered by consumers without questioning the faults of the manufacturer. If carefully examined, the Consumer Protection Act actually adopts the concept of strict liability because in addition to in 19 paragraph (1), Article 28 stipulates that proof of whether or not there is an element in the compensation claim, as referred to in article 19, Article 22, and Article 23, constitute the burden and responsibility of the business actor [5].

In Indonesia defects in products or defective products are defined as any product that cannot fulfill its intended purpose, either due to intentional or negligence in the process or caused by other things that occur in its circulation, or because it does not provide security requirements for humans or their property in its use, as expected by people in general." [6].

Therefore, sale and purchase of goods and/or srvicesis the most often undertakenactivity by everyone, both on a small scale and a large scale. However, not all of these buying and selling transactions are done correctly. Sometimes there are sellers who have bad intentions to sell items that have hidden defects in order to pursue maximum profits. In general, hidden defects can be interpreted as a defect that is unknown at the time of sale, which if known can cancel the purchase or the price offered is reduced. In fact, we often experience this, but for buying and selling on a small scale, even though there are hidden defects in goods sold, usually most buyers just give up their goods; maybe because the value of goods is smaller than the effort needed to demand compensation. Different conditions can be seen if we sell and buy on a large scale, the transaction value is quite large, such as buying and selling vehicles, furniture, and so on. But again, not all goods are of good quality; there are some items that turn out to have hidden defects.

Apart from the Civil Code, defects in hidden products are also regulated in Law Number 8 of 1999 concerning Consumer Protection (or "UUPK"). In this $U U P K$, the principle of "Product Liability" or product responsibility is re-introduced, where the producer is responsible for the goods made which cause losses due to defects in the goods. In Article 8 of the $U U P K$ it is also stated that "business actors are prohibited from offering, producing, advertising an item and/or service incorrectly, and/or as if the item does not contain hidden defects. With these rules, it is clear that the seller has responsibility for any hidden defects in the item. However, often sellers argue by installing a provision that "items that have been purchased cannot be returned or exchanged".

One of the factors of enforcing the rules of law regarding consumer rights is an absolute effort to foster the attitudes and behavior of consumers themselves, so that they can become responsible consumers, namely consumers who are aware of their rights as consumers.

Losses borne by the consumers due to defective products are regulated in the provisions of Article 1367 of the Civil Code. Hence, losses suffered by consumers as a result of consumption of consumer goods can be classified into material losses, namely in the form of 
losses on goods purchased, and immaterial losses, namely losses that endanger the health and/or soul of consumers.

\subsection{The Settlement of the Cases of Sales and Purchaseof Used Carsin Schowroom Companythat are Incompatible with Those Presented in the Ads}

According to provisions inArticle 19 paragraph (1) of the Republic of Indonesia Law Number 8 of 1999 concerning Consumer Protection, consumers who feel disadvantaged shall be justified to directly demand compensation from producers, and producers must provide responses and/or solutions within seven days after the transaction takes place. Losses that can be prosecuted, in accordance with Article 19 paragraph (1) of the Republic of Indonesia Law Number 8 of 1999 concerning Consumer Protection, comprisethe losses due to damage, pollution, and other losses resulting from consuming goods and/or services. The compensation can be in the form of returning money for the purchase of goods and/or services; replacement of goods and/or similar services or equivalent in value; health care; and appropriate compensation.

The choice of the form of compensation depends on the loss suffered by the consumer. For consumers who are harmed by consuming products of goods and/or services that can harm and endanger health, the consumer concerned can file a lawsuit to the court to obtain justice for the rights violated by the manufacturer. Submitting a lawsuit to a court is carried out in accordance with civil procedural law, where the principle of a waiting or passive judge applies, which in other words is that litigation initiatives come from interested parties.

In compensation claims based on illegal acts, the plaintiff's consumer must prove that the defendant's manufacturer has been guilty of doing something that caused the plaintiff a loss. Proof of awrongdoing is absolutely necessary because the basis of liability here is a misconduct. In Article 28 of the Law of the Republic of Indonesia Number 8 of 1999 concerning Consumer Protection, it is stipulated that proof of whether or not there is an element of error in the claim for compensation is the burden or responsibility of the business actor (producer). This is called the principle of strict liability. However, what is proven by the defendant's producer should be limited, that is to say the defendant's producer only proves that he/she has done everything related to the security of the production process so that it produces good and healthy products while proving that he is not liable for the losses incurred as the risk.

As indicated by the results of the investigation on the company Showroom owned by PT. Putra Dewata Motor, on August 15, 2018, when a consumers is harmed by the purchase of a used car that is not in accordance with what was presented in the advertisement and also not in accordance with the agreement, the consumer concerned can make some efforts to obtain justice, which among others is the initial action in credit agreements are established, namely preventive actions, namely actions taken to reduce the likelihood of the occurrence of risks that occur, namely by providing understanding to consumers about the agreed agreement clauses. In addition, repressive actions are also taken in the form of active actions if violations of the loan agreement clause occur, so that the application of sanctions in accordance with the agreement in the form of fines and cancellation of agreements is carried out. Likewise, if the showroom company is proven to have committeda mistake that caused a loss to the consumer, the company concerned must pay compensation as long as the damage to the car purchased by the consumer.

Thus, consumers who are harmed by purchasing a used car that is not in accordance with the specifications stated in the advertisement can make several efforts in addition to preventive and repressive measures, and to obtain justice, consumers who suffer losses can make 
complaints to consumer protection institutions, dispute resolution outside the court, and dispute resolution through the court.

\section{Recommendations}

4.1 It is recommended for used car showroom businesses for not to overlook the consumers' safety for the sake of obtaining as much profit as possible. The misconducts of business actors that harm consumers demand the realization of the role of consumer protection institutions.

4.2 It is also recommended to Indonesian government to take an active role realisingthe actions of providingholistic protection for consumers rather than to take much efforts of accommodating their complaints, hence more importantly all submiited complaints must be taken seriously in to account so that the concerned consumers obtain justice.

\section{References}

[1] A. Widjaja, Gunawan., \& Yani, Hukum Tentang Perlindungan Konsumen. Jakarta: PT Gramedia Pustaka Utama, 2003.

[2] N. Syawali, Husni., \& Imaniyanti, Hukum Perlindungan Konsumen. Bandung: Mandar Maju, 2000.

[3] Barkatullah, A. H.: Hak-Hak Konsumen. Nusa Media, Bandung (2010)

[4] Ahmadi, M., \& Yodo, S.: Hukum Perlindungan Konsumen. Rajawali Pers, Jakarta (2004)

[5] Tahir, T.: Tanggung Jawab Produksi Dalam Perspektif Hukum Perlindungan Konsumen. Balai Pustaka, Bandung (2000)

[6] Nasution, A.: Hukum Perlindungan Konsumen Suatu Pengantar. Daya Widya, Jakarta (1999)

[7] "Indonesian Book of Civil Code"

[8] "Law of the Repubic of Indonesia No. 40 of 2007 on Limited Liability"

[9] "Law of the Repubic of Indonesia No. 8 of 1999 onConsumer's Protection" 